\title{
The Competences of Teaching Staff and Principals in the Context of Educational Innovation and School Development
}

\author{
Phạm Minh Gian ${ }^{1} \&$ Dặng Quoc Bao ${ }^{2}$ \\ ${ }^{1}$ Dong Thap University, Vietnam \\ ${ }^{2}$ The Institute of Vietnamese Intelligence (Vietnam's Union of Science and Technology Association), Vietnam \\ Correspondence: Phạm Minh Gian, Dong Thap University, Vietnam. E-mail: pmgian@dthu.edu.vn \\ Received: February 20, 2020 \\ Accepted: September 11, 2020 \\ Online Published: December 26, 2020 \\ doi:10.5539/ies.v14n1p65 \\ URL: https://doi.org/10.5539/ies.v14n1p65
}

\begin{abstract}
Since the beginning of $21^{\text {st }}$ century, Vietnam has achieved significant educational achievements, especially in the improvement of general education network and teaching quality. The reality has showed that working effectiveness of a school totally depend on the competence of its principal and of the entire teaching staff. Once these two entities meet the required capacities in the context of innovation in education, leadership and management, they will surely make an important contribution to the development of the school, fulfilling the long-term national goal of comprehensive innovation of Vietnamese education in the current period. In the article, the authors give first an overview on the concept of competence and then the necessity for "competence" of the principal and teachers in view of their roles in school development with an aim to further improving the quality of school management and that of teaching and learning in response to the motional cause of education innovation.
\end{abstract}

Keywords: competence, Vietnamese school, teacher, principal

\section{Introduction}

\subsection{Legal Background of Improving the Competence of Teaching Staff and School Management}

The broad tendency of globalization, international integrity, knowledge-based economy, boom of information technology development... have affected all nations in term of their overall aspects of life, including education. It is, therefore, demanded that education should be innovated by the involved education leaders and managers to effectively respond to these changes through their strategies and policies.

In June 2012, the Prime Minister issued Decision No. 711/QD-TTg, approving the "Education Development Strategy, period 2011-2020", pointing out in Section V - Educational Development Solutions for the 2011-2020 period - that it is necessary to successfully implement eight solutions, of which solutions 1 being a breakthrough solution and solution 2 being a key one: developing the teaching staff and school administrators respectively so as for the Strategic goals to be reached.

In November 2013, in the $8^{\text {th }}$ Plenum Meeting of the Central Party Committee, term XI a Resolution No. 29-NQ/TW on "radical and comprehensive renovation of education and training, meeting the requirements of industrialization and modernization in the context of socialist-oriented market and international integration" was passed. Hereby, at Point 6, Section III, Duties and Solutions of Part B. Radical and Comprehensive Innovation of Education and Training, it is clearly affirmed: developing the teaching staff and school managers, meeting the requirements of education and training innovation.

The two above matters share a common denominator: Establishing master plans, projecting plans to train, retrain teachers and foster educational management staff according to the requirements of improving their quality, responsibility, ethical standards, and professional competence. In a more explicit expression, in the context of the era of Industrial Revolution 4.0, one of the essential requirements of modern education is to urgently, continuously and regularly provide the teachers and school managers with training and fostering courses for the improvement of their capacities. In the light of this sense, in this article, the authors present: Awareness of the "concept of competence"; Discussion on the competence issue of teachers, school managers; Recommendations on the policies for training and re- training the needed competencies for teachers and principals toward meeting the roles and responsibilities of leadership, management and teaching work in the context of innovating and developing Vietnamese schools. 


\subsection{The Rationale of Improving the Competence of Teaching Staff and School Managers}

Competence is the universal characteristics of one's personalities. It is clearly defined in the Dictionary of Vietnamese that: "Competence is a personal ability, his subjective or natural conditions to perform a certain activity ..." (Hoang Phe et al., 2009)

In a normal sense, competence refers to the aspect "talent" in one's personality while quality implies the aspect of "virtue". However, in today's expression, quality is an aspect of competence. For example, concerning to a person's leadership competence, it is refered to both his "talent" and "virtue" in social conditions.

In a Dictionary of Education, competence is defined as the unborn or learned ability that allows a person to succeed in a physical, mental, or professional activity. One's competence is usually expressed in his ability to perform an activity or a task. Competence is only effective when it is proven in activity performance, in the opposite case, it is only assumed or not real. Competence can be born or established as the process of practice is developed by experiencing or by learning in accordance with individual's unique characteristics.

Competence is seen as the ability of a person to face new problems and situations in which he can recall the information and techniques that he used in previous experiments.

In corresponsive to pedagogical and educational actions, competence is divided: the motor-type competence is manifested by the nature and quality of motion; intellectual competence is manifested by intellectual approaches with the latter demonstrating one's sensitivity, similarly to emotional competence.

The ability of a person is measured by completing complex tasks, which requires the execution of many operations on the tasks that people often encounter while practicing a profession. (Bui Hien et al., 2013)

Nowadays, in a deriving process as talking about the concept of competence, it may point to the concept of "performing competence". The Vietnamese Encyclopedia of Psychology and Education has it in an entry that: Competency is an ability needed to be able to complete one or a number of professional work. Performance competence is not the common potentiality of every person, but is the ability to carry out a specific job of the profession, including the knowledge, skill and attitude that are applied in an integrated manner to accomplish a certain task prescribed in set of job's standardized duties under necessary conditions. To be able to work in a job position/title of an occupation, the employees must be able to complete all tasks of this profession. Therefore, in modern vocational training, performance-based training is being increasingly and popularly applied (Phạm, 2013)

The competence mentioned in this article is based on the professional demands for functions, responsibilities and roles of the teaching staff and principals in the current educational context.

\section{Method}

In this article, the research methods include theoretical analysis, modeling and synthetics of educational experience and by reviewing educational accomplishments during personal professional work for useful conclusions.

In the article, in addition to the authors' educational experience, we have taken reference on other researchers' works.

- Ho Chi Minh, a Vietnamese national revolutionary hero, an outstanding man of culture and a great teacher.

- Chu Van An, a model teacher of Vietnam in all times

- Teacher, Professor Nguyen Canh Toan, the holder of immense research projects, also known as a talented mathematician and as a model teacher who devoted his whole life to the cause of national education innovation and creativeness.

\section{- Professor Klaus Schwab, Chef Executive of World Economic Forum}

- John Vu, former Technical Fellow and Chief Engineer at the Boeing Company, who has taken important positions in several US' universities and corporations, who wrote the valuable nomograph of "Education in the Era of Knowledge"

- Carl Rogers, Johm Home, Maria Montessori, John Dewey, Ernest Melby,... are also the authors whose ideas were in our reference.

\section{Results and Discussions}

\subsection{Teacher's Competence in the Context of Education Innovation}

In order to effectively respond to the cause of educational innovation, teachers are required to constantly improve their competence and qualification. School managers must promulgate guidelines and policies so that their 
teachers/teaching staffs are all included in these renovation policies, which helps them constantly improve their personalities. The following discussions focus its concentration on the management of teachers and teaching staff, helping them fulfill their sacred mission in educational innovation.

\subsubsection{Four Roles of a Teacher}

No matter how teaching techniques and teaching technologies have been changed and developed towards the society's increasingly developed direction, in many countries, Vietnam included, four types of teaching styles are intermingling conducted, thus leading to four roles of a teacher.

Traditional teaching: in this type of teaching, the teacher plays the role of a commander and his students obey his commands. Students are required to "imitate" the knowledge disseminated by the teacher.

Eliciting teaching: in this type of teaching, the teacher is a designer and students execute his ideas. Students are required to "reproduce" the knowledge provided by the teacher.

Active teaching: in this type of teaching, the teacher has a leading role while the student perceives his communication. Students are required to "reproduce" the knowledge provided by the teacher.

Constructive teaching: in this type of teaching, the teacher has the role of a mentor, an inspiratory and students must discover the objective reality that both teachers and students are interested in. The students "create" the knowledge elicited by the teacher.

Table 1. Teaching styles and the requirement for the roles of teachers

\begin{tabular}{lccc} 
& & & \\
Teaching Style & Teacher & Student & Development of knowledge \\
& & & \\
\hline Traditional & Giving commands & Obeying & Imitating \\
\hline Eliciting & Designing Suggesting ideas & Implementing & Reconstructing \\
\hline Active & Leading Proposing objectives & Perceiving & Reproducing \\
\hline Constructive & Mentoring Inspiring & Discovering & Creating \\
\hline
\end{tabular}

In reality, students are not homogeneous in term of their characteristics. If two criteria of intellectual development and learning attitude are considered, there are four types of students in every class: Smart - Hardworking; Intelligence - Lazy; Slow - Hardworking; Slow - Lazy.

The teacher, following the working motto "Huu giao vo loai" (nobody is impossible to be taught) must be flexible, successfully fulfills his work responsibilities in all 4 aspects: Commander; Designer; Mentor, Inspiror.

A dedicated teacher is a manager - a manager without a red stamp, who has teaching skills, teaching styles so that every student can be able to keep up with the imposed "teaching-learning requirements".

Professor Nguyen Canh Toan, also a teacher used to suggest teaching students in a spirit of dividing 4 powers: competence, attraction, permeability, and creativity.

Pedagogical labor of teachers, considered as "Su hinh" (The noble teacher - Ho Chi Minh's teachings) is, therefore, quite tiring. Economic - educational policies, therefore, must cover the above-mentioned characteristics in order that their contents become "thau tinh dat ly" (comprehensible and plausible).

\subsubsection{Teacher's Ideal-Teacher's Virtue and Teacher's Art of Teaching}

Teacher's ideal - Teacher's virtue and Teacher's art of teaching must syndronously develop in a positive direction so as to bring forth effective teaching. When only one of the factors develops in a negative orientation, teaching becomes less effective immediately.

a. Teacher's ideal: teacher's professional ambition

A message of "All are for dear students" has been launched in Vietnamese schools in the 1960s and this message remains a sense of urgency in today schools.

b. Teacher's virtue

Over 650 years ago, teacher Chu Van An (1292 - 1370), who was honored as a model teacher of Vietnam, and who petitioned to the King the Appeal of "Seven Deadly Sins", gave his teachings to disciples via eight words: "Cùng 


\section{lý - Chính tâm - Trừ tà - Cự bế".}

"Cung Ly": Thoroughly grasp all the arguments of matters.

"Chinh Tam": Train the righteous mind, stay away from the dull mind, the wrong mind.

"Tru Ta": Being against nonsensical theories.

" $\mathrm{Cu} B \mathrm{Be}$ ": Having the energy to overcome adversities and difficulties.

The eight teachings that the teacher Chu Van An mentioned about teacher's virtue still remain unchanged in term of the meaning for the practice of professional virtue of the Vietnamese teachers in the current context.

c. Teacher's art of teaching

This includes the teachers' all arts of teaching as in a school teachers are supposed to take three job responsibilities: "Providing students with knowledge, Teaching students to become mature individual and teaching students to learn a profession", which means the work of transmitting virtue, explanation and career pursuit to students.

The teachers' art of teaching is expressed in sixteen words:

- Treatment towards the students: Dụ - Trợ - Khải - Phát

- Attitude with the lessons: Kế - Triển - Kiểm - Hồi.

- Pedagogical skills: Huấn - Luyện - Lượng - Bồi.

- Pedagogical manner: Ấn - Uy - Đức - Pháp.

$D u$ : Leading students into the learning process.

Trọ: Helping students overcome difficulties.

Khåi: Awakening students to reach noble living values.

Phát: Developing students' personalities.

Kế: Planning the delivery of lesson contents.

Triển: Implementing a determined teaching plan.

Kiểm: Testing, assessment.

Hồi: Giving feedback.

Huấn: Coaching students to grasp new knowledge.

Luyện: Training practical skills for learners.

Luơng: Giving objective assessment to students'studies.

$B$ î̀ : Fostering students of their knowledge and skill deficiencies.

$\hat{A} n$ : Being tolerant to students.

Uy: Becoming serious in conducting pedagogical regulations so that students can fulfill their duties.

Đúc: Being able to apply educational methods to motivate students.

Pháp: Showing students how to strictly observe the school's regulations and rules. 


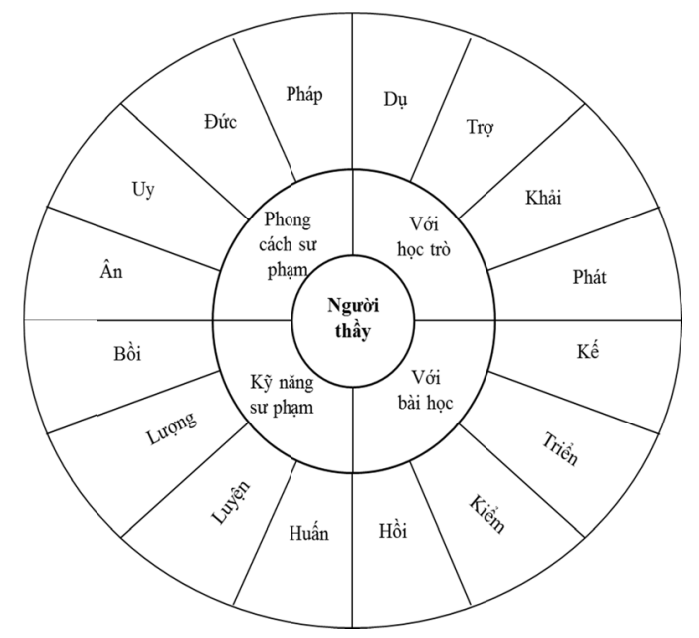

Figure 1. Teacher's behavior under the working motto "All are for dear students"

\subsubsection{Discussions on Today Teachers' Roles}

Our predecessor's essence must be updated with the value of the modern time. Let some of the following comments be mentioned so that a Vietnamese teacher must take into account in order for his "Sư đạo - Sư đức - Sư thuật" (Teacher's ideal, teacher's virtue and teacher's art of teaching) to be developed synchronously.

In his talk in early 2017, Professor Klaus Schwab, Executive Director of the World Economic Forum (WEF) expressed his concern: "We are in a moment of historical turning point, in which we are facing with turbulence on economy, politics, migration, terrorism, and the cracks institutions, ethical standards, leadership competence...". He proposed the concept of "four Cs" that any modern persons, no matter what their profession will be, need regular practice.

C1: Critical thinking

C2: Creativeness

C3: Communication

C4: Collaboration

(Schwas, 2018)

Applying the above comments to the schools, the teachers must pass that " $4 \mathrm{Cs}$ " on students. Again, to do this, the teachers must constantly accumulate values of " $4 \mathrm{Cs"}$ ".

Carl Rogers, an American humanitarian educational psychologist, gave the following advice to teachers: Be regularly mindful of the students' affection; Regularly take more advantage of students' purpose in the interaction activities of the lesson time; Have more talks with students; Give regular praisals to students; Having appropriate communication with students; Constantly associate the learning contents with the experience of each specific student (the teacher's lecture satisfying the students' current needs) and smile more to students".

John Home stressed that: "A teacher who talks long and talks a lot is students' enemy."

Maria Montessori (1870 - 1952): "Teachers will have to learn to keep quiet instead of talking, observing instead of instructing, and putting on a cloak of humility and passion instead of the proud look of a person who never makes mistakes. "

John Dewey (1859-1952): “The teacher is not a judge, nor a person of authority in the classroom, but a member of the classroom so the teaching method will be something natural, not hindering students' natural development nor turning young children into old men. Every teacher should be aware of his or her professional dignity that he (she) is a social servant who is assigned to maintain the proper social order and ensure proper social development. Accordingly, the teacher is a true prophet of god and a genuine tutor in the kingdom of god.

Carl Jung (1875 - 1961): "We show our respect to the distinguished teachers, but we must express our infinite gratitude to the teachers who have warmed our hearts. The warmth of the soul is a vital factor for the young souls."

Ernest Melby: "One of the most important things for a teacher is to give his students comfort and condolence and 
take away their sad anxiety".

(Dang \& Pham, 2019)

\subsection{Principals' Competence in the Context of Educational Innovation}

\subsubsection{Principal: Three Roles and Three Functions}

The principal, the head of the pedagogical team, has three roles: an orchestra conductor, a commander of a military unit, a football coach for a competition. At the same time, the principal has the following three functions: a leader who directs the overall work of the school, the specific manager of educating - teaching so that new personalities are created, a meticulous administrator of capital sources assigned to the school by the society to transform personalities into human resources.

\section{a. Principal - "the orchestra conductor"}

John Vu, Technical Fellow and Chief Engineer at The Boeing Company, who used to hold many important positions in many universities and major economic groups in the US, wrote in a valuable monograph of "Education in the age of knowledge" (T. V. Ngo, 2016).

John Vu remembered a lunch when he met with Benjamin Zander, the famous conductor of a symphony orchestra in Boston, who gave a message in that interesting exchange: "The conductor is not the one who proves his creativity through the musical instrument but is judged by their ability to create an environment in which musicians' talent can emerge and the quality of the performance can be experienced by the audience. His job is not different from that of a school principal."

John Vu went on with what he has learned from Benjamin Zander's ideas by saying that: "For several following days, the concept of the principal as the conductor had invaded my mind. In a school, when the teachers or the learners are not doing well, how many principals will take this concern: "What is it that I personally do not encourage my teachers or my students to do as well as they should?" Maybe I do something that doesn't boost the performance that every teacher is capable of doing."

John Vu emphasized: "In an orchestra, there is a conductor and many musicians, the conductor is the leader and the musicians are the managers who manage their own instruments to play the music... Leadership and management are not the same but they are linked and mutually complemented each other. The musicians's job is to show off their best artistic power. That means it is the job of a teacher/professor to organize classes according to their best qualifications. The conductor's job is to inspire and motivate. The principal's job is also inspiring and encouraging. I like such comparison". (T. V. Ngo, 2016)

\section{b. Principal - "A commander of a military unit"}

The idea of comparing the Principal - Conductor was also mentioned by Peter Drucker-a famous practical manager. More than that, Peter Drucker requires the principal to be the commander of a military unit. A principal is aware of the ideas of Peter Drucker. "The broad audience that the principal affects is the students" (through the school's pedagogical collective).

Principals by their mapped-out guidelines and plans, must make the collective of student - "the central subjects of the teaching process" to possess a sense of discipline in learning and working, a desire to best develop their personalities in accordance with the motto "Caring without indulging, respecting but persevering the principles that require students to act in accordance with Politeness - Gratitude - Honesty - Self-respect". Similarly, principals must have the manner and attitude of the commander of a modern army unit to urge the students to practice " $4 \mathrm{Hs}$ and 3Ss"

4H: Học (Learning) - Hòi (Questioning) - Hiểu (Understanding) - Hành (Acting)

3S: Sống hẳn hoi (Living soundly) - Sống chừng mực (Living moderately) - Sống sáng tạo (Living creatively)

\section{c. Principal - A coach of a football team in a competition}

Today schools operate as factories - factories without chimneys but producing personality - manpower.

The principal, the head of the school, must always be sensitive to the law of value - the law of supply and demand of the market - the law of competition, the law of time in term of economic angle. Peter Drucker himself had once demanded: "The school must operate as an economic unit" and should not behave in such a way as "No matter when long nights come and long days arrive, schools will be exempted with the economic concepts". That means with the help of specialized departments, the principal must know the cost of training for each school year.

The principal must control the activities of the school's staff working in the departments Education \& of 
Administration, of Testing and Quality Assurance, of Marketing, ... and also the faculties/academic departments... like controlling the operation of a football team in a competition. A principal is supposed to have a "feeling of directing a rough match" in view of the school's state under the condition of finance use being funded and required provision of workforce being imposed by the society. Principals must, therefore, not be "in a perfunctory manner" or "taking something for granted" in term of the category of "economic quota in teaching", a standard to be applied in teaching."

\subsubsection{Principal's Three Capacities}

Principals' capacities must be harmoniously dedicated to: leadership, management and school management competence. True leadership capacity requires the principal to run the school in such a way that every member considers the sense of "Living in the spirit of love" as a key value of life, taking the "development goal" as a priority, and codes of ethics as a motivation to work.

The management competence requires the principal of the school to ensure that the school members thoroughly grasp the slogan of "Living and fulfilling the given duty" is the key value of life, and that clarifying the "Development solution" is prioritized, and that justice as a working motivation.

The management competence requires the principal to run the school so that all members think that "Living to create benefits" is a key life value, with a priority given to attaining "spiritual/material achievement" and with a consideration of legal affairs as a working motivation.

\subsubsection{Some Formulas Describing the Principals' Work}

a. Formula describing the principal's overall leadership

$$
\mathrm{L}=7 \mathrm{~S}
$$

L: Leadership

S1: Staff (number, quality, structure, synergy)

S2: Structure (internal structure-an emphasis on the school's internal relationships)

S3: System (general system-an emphasis on the school's internal and external relationships)

S4: Strategy (action strategy-defense, restrain, attack)

S5: Skill (required management skills)

S6: Style (manipulated managing styles)

S7: Super priorities (top priorities in urgent need of solution)

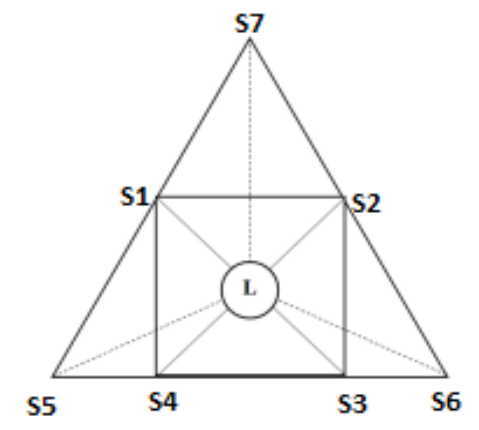

Figure 2. The 7S management model

\section{b. Formula describing the principal's specific management}

$$
\mathrm{M}=5 \mathrm{~m}
$$

\section{M: Management}

$\mathrm{m} 1$ : manpower

$\mathrm{m} 2$ : money

m3: machine-equipment 
m4: material

m5: marketing

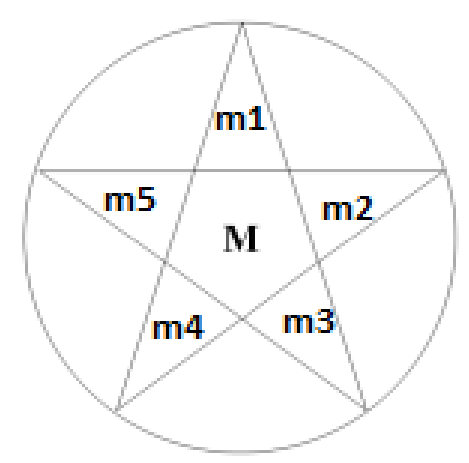

Figure 3. The 5M management model

\section{c. Formula for the principal's meticulous administration}

Three formulas describing the meticulous management of school' development factors:

$$
\mathrm{A} 1=4 \mathrm{P}
$$

A1: Administration

$\mathrm{P} 1$ : Product (the specification of using teaching program)

P2: Price (the cost offered for the implementation of the teaching program)

P3: Place (location for the application of teaching program)

P4: Promotion (measures of consumption promotion)

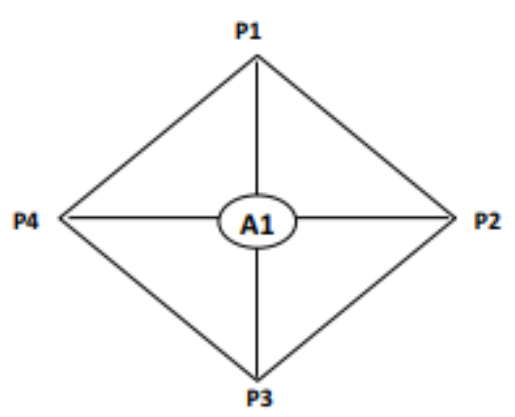

Figure 4. The 4P administration model
$\mathrm{A}_{2}=4 \mathrm{C}$
A2: Administration
$\mathrm{C} 1$ : Consumer (subjects to whom the teaching program is intended)
$\mathrm{C} 2$ : Cost (the expenditure for the implementation of teaching program)
$\mathrm{C} 3$ : Convenience (service offering convenience to the users of teaching program)
C4: Communication (communication with the customers) 


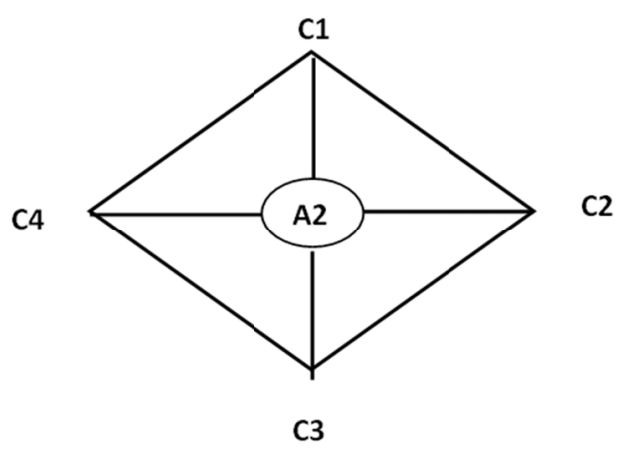

Figure 5. The $4 \mathrm{C}$ administration model

When a principal is in the "feeling of directing a rough football match", he will surely be sensitive in determining whether he will apply the model of $\mathrm{A} 1=4 \mathrm{P}$, or $\mathrm{A} 2=4 \mathrm{C}$ or not.

A1 attaches the importance to the offered cost of implementing a new teaching program while A2 is concerned with the training cost of implementing a new teaching program.

$$
\mathrm{A}_{3}=5 \mathrm{~W}+\mathrm{H}+2 \mathrm{Q}
$$

In their general school management work, principals must grasp seven questions below

- What/Why?: What should I do and why should I do it?

- Who/Why? : Who should I work with? Why should I work with these persons?

- Where/Why?: Where should I do it? Why should I do it there?

- When/Why?: When should I do it? Why should I do it at that time?

- How/Why?: How should I do it? Why should I do by that way?

- Quantity/Why?: To what extent should I do it and why should I do it to that equinity?

- Quality/Why?: How much should I do it and why should I do it to that much quality?

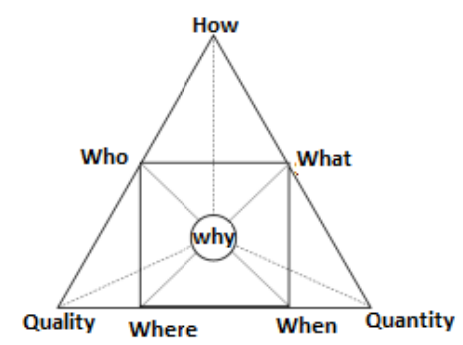

Figure 6. The $5 \mathrm{~W}+\mathrm{H}+2 \mathrm{Q}$ administration model

\subsubsection{The Twelve Sets of "2" of a Principal}

No matter what situation he faces in operating the school, a principal needs the following three general capacitiess: (i) ability to think, especially critical thinking; (ii) ability to organize work; (iii) ability to establish relationships with involved persons.

A principal is supposed to thoroughly grasp twelve sets of "2" as follow:

Three sets of critical thinking skills: he has to know (i) himself \& others; (ii) his strength \& the times; (iii) what is enough \& when it is time to stop;

Four sets of job capacities: Doing the right things \& Doing the planned tasks correctly; (v) Being disciplined \& flexible; (vi) Taking active initiatives \& taking farsighted visions; (vii) Paying attention to the work as as whole \& paying attention to the work in specific details;

Five sets of establishing relationships: (viii) Taking abligation \& Managing; (ix) Competiting \& yielding; (x) Taking suction \& repulsive force; (xi) Being authoritive \& tolerant; (xii) Being assertive \& democratic. 
In his managing the school, the principal needs to apply "Considerion - Contrivance - Choice" to realize the set goals.

In general: $\mathrm{F}$ (Operating the school $)=\mathrm{f}(\mathrm{a}, \mathrm{b}, \mathrm{c})$

a: Consideration: finding the balance of the subjectives and the objectives

e.g. When you are in Rome, do as the Romans do

Young aged persons will do small things, depending on his strength.

b: Contrivance: finding the compatibility between the objectives and personal ability, i.e. cut your coat according to your cloth.

c: Choice: to find the convergence point of one's internal and external strength, i.e. look before you leap.

\subsubsection{Principal's Wisdom-Based Management}

Wisdom-based management is management of: "wise-smart", "moderate" management, or "positively effective" management.

Ngo Thi Nham (1746-1803), a culture researcher, had the message: "minh triết dĩ báo than, vô cứ vu lê, vô khốn vu thạch," firugatively meaning that a person of wisdom will know how to control himself under any circumstances and will not stumble into rock on the street or get trapped in tree's branches)

The knowledge of intelligent management today is named Phronesis and was proposed by a Japanese scholar Nonaka, including:

(i) The ability to appreciate the good.

(ii) The ability to share common context with others so that a common knowledge space will be created and the goals are reached.

(iii) The ability to grasp the nature of phenomena in close connection with the good.

(iv) The ability to use narrative language to refactor the particularity into generalization and vice versa.

(v) The ability to use the necessary political means to realize concepts and reacg the set goals.

(vi) The ability to encourage Phronesis of others to build up the organization flexibly.

Nonaka has commented: Ho Chi Minh is a wise leader. (T. L. Ngo, 2016)

\section{Conclusions}

In general, the competence of teachers and principals always plays an important role in the development of schools under any eras. It is noticeable that in the current context of science and technology - the Revolution 4.0, teachers and principals are more and more important in term of their capacities and these two parties need to be able to respond quickly to the rapid changes of the times.

Leaders and educational managers of all levels should attach great importance to the training and retraining of competencies as presented to the teachers and school principals via training, re-training courses and reality experience programs. Each teacher and principal must personally take initiative in doing research, further study, and train themselves in practice in order to attain the needed competences to meet the professional requirements, functions, responsibilities, and finally successfully complete their work of leadership, management and teaching.

\section{References}

Bui Hien et al. (2013). Education Dictionary. Polytechnic Dictionary Publishing House, Hanoi.

Communist Party of Vietnam. (2013). Resolution of the 8th Plenium of the Central Party Committee, term XI. The Office of the Central Party Committee, Hanoi.

Dang, Q. B., \& Pham, M. G. (2019). The Flow of Vietnamese Education. The Publishing House of Information and Communication, Ha Noi.

Hoang Phe et al. (2009). Dictionary of Vietnamese. Da Nang Publishing House.

Martin-Kniep, G. O. (2011). Eight reforms for a good teacher (Le Van Canh Trans.) Vietnam Education Publishing House, Hanoi.

Marzano, R. J. (2011). The art and science of teaching (Nguyen Huu Chau trans., Le Van Canh edited). Vietnam Education Publishing House, Hanoi.

Ngo, T. L. (2016). Professor Ikujiro Nonaka: "Ho Chi Minh is a wise leader. E-World Security. Retrieved from 
http://antgct.cand.com.vn/So-tay/Giao-suikujiro-Nonaka-Ho-Chi-Minh-la-mot-nha-Lanh-dao-minh-triet-37 9283/

Ngo, T. V. (2016). Education in the age of knowledge (Vietnamese edition). Labor Publishing House, Hanoi.

Phạ, M. H. (2013). Vietnam Encyclopedia of Educational Psychology. Vietnam Education Publishing House, Hanoi.

Schwas, K. (2018). Industrial Revolution 4.0. The Publishing House of The World in collaboration with The Ministry of Foreign Affairs, 2018.

Stronge, J. H. (2011). The qualifications of an effective teacher (Le Van Canh trans.). Vietnam Education Publishing House, Hanoi.

\section{Copyrights}

Copyright for this article is retained by the author(s), with first publication rights granted to the journal.

This is an open-access article distributed under the terms and conditions of the Creative Commons Attribution license (http://creativecommons.org/licenses/by/4.0/). 